\title{
Ablation of Gene Expression of N-Methyl- D-Aspartate Receptor One by Antisense Oligonucleotides in Striatal Neurons in Culture
}

\author{
P.W. Lui ${ }^{a}$ C.W. Yeung ${ }^{a}$ W.H. Yung ${ }^{c}$ Y. Shi ${ }^{\text {b }} \quad$ L.W. Chen ${ }^{d}$ Y.S. Chan ${ }^{\mathrm{e}}$ \\ K.K.L. Yung ${ }^{a}$ \\ ${ }^{a}$ Department of Biology and ${ }^{b}$ School of Chinese Medicine, Hong Kong Baptist University, Kowloon Tong, \\ ${ }^{c}$ Department of Physiology, The Chinese University of Hong Kong, Shatin, ${ }^{d}$ Institute of Neurosciences, \\ The Forth Military Medical University, Xian, and ${ }^{\mathrm{e}}$ Department of Physiology and Research Center of Heart, \\ Brain, Hormone and Healthy Aging, The University of Hong Kong, Hong Kong, PR China
}

\section{Key Words}

Basal ganglia $\cdot$ Neostriatum $\cdot$ lonotropic glutamate receptors $\cdot$ Neuronal cell death $\cdot$ Glutamate excitotoxicity - Patch clamp - Reverse transcriptasepolymerase chain reaction - Immunofluorescence . Gene therapy $\cdot$ Neuroprotection

\begin{abstract}
In the present study, a twenty-mer antisense oligonucleotide specific for $\mathrm{N}$-methyl-D-aspartate receptor one (ANR1) was applied to striatal neurons in primary cell culture. The ANR1 was found to be specific and nontoxic. Significant reductions in expression of NR1 mRNA and proteins were resulted after a single dose of ANR1 transcripts. Interestingly, there were reductions in total NR1 proteins but two phosphorylated forms of NR1 proteins at serine 896 and 897 residues were not reduced. There was also no change in the pattern of distribution of NR1 immunoreactivity in the striatal neurons. In addition, significant reductions of NMDA-mediated peak inward current were found after application of a higher concentration of ANR1 (20-100 $\mu \mathrm{M})$ by patch clamp recordings. The present results indicate that ANR1 is a use-
\end{abstract}

ful agent in reducing NMDA receptor functions. The present data thus provide detailed cellular and molecular mechanisms to explain our previous findings of amelioration of motor symptoms in a rat model of Parkinson's disease. More importantly, application of ANR1 was also found to display neuroprotective effects of striatal neurons against NMDA-induced excitotoxic cell death. The findings have implications in development of new approach in prevention of cell death in neurodegenerative diseases and new treatments for these diseases.

Copyright (C) 2005 S. Karger AG, Basel

\section{Introduction}

Glutamate-induced excitotoxic cell death is implicated in neurodegenerative diseases [1,2], including motor disorders, namely Parkinson's disease [3-5] and Huntington's disease $[6,7]$. N-methyl- $D$-aspartate (NMDA) receptors are one of the major classes of ionotropic glutamate receptors that mediate excitotoxic cell death $[8,9]$.

Functional native NMDA receptors are composed of heteromeric subunits (NR1, NR2A-D and NR3A-B) [10$20]$ and their functions depend upon subunit composi-

\section{KARGER}

Fax +41613061234 E-Mail karger@karger.ch www.karger.com
(C) 2005 S. Karger AG, Basel

1424-862X/05/0146-0303\$22.00/0

Accessible online at: www.karger.com/nsg
Prof. Ken K.L. Yung

Department of Biology

Hong Kong Baptist University

Kowloon Tong, Hong Kong (PR China)

Tel. +852 3411 7060, Fax +852 3411 5995, E-Mail kklyung@hkbu.edu.hk 
tions [10-15]. Previous findings indicate that NR1 is the major subunit that forms a functional NMDA channel. The roles of NR2 subunits are thought to modulate the functions of the ion channel.

Degeneration of neurons in the basal ganglia is a hallmark for motor disorders [21]. A degeneration of medium spiny neurons, the striatal projection neurons, in the neostriatum is the cause of Huntington's disease [22]. In the neostriatum, NMDA receptors are found to be expressed in most of the subpopulations of striatal neurons including the medium spiny neurons [23] and involved in motor regulation in the neostriatum and circuitry in the basal ganglia [24, 25].

Recent findings in our laboratory [26-28] and others [29] indicate that intrastriatal administrations of antisense transcripts specific for NMDA receptor subunits, i.e. antisense specific for NR1 subunit (ANR1) and NR2B subunit, into rats results in reductions of NR1 and NR2B mRNA and protein expressions. Interestingly, intrastriatal administrations of ANR1 in 6-hydroxydopaminelesioned rats, an animal model of Parkinson's disease, induce an amelioration of motor symptoms in the rats [28]. ANR1 is therefore thought to be a potential antiparkinsonian agent and may have applications in treating other related motor disorders such as Huntington's disease, which is primarily resulted from a degeneration of striatal neurons [7].

Despite our previous observations, physiological and pharmacological effects of ANR1 to striatal neurons is, however, not clear. The objectives of the present study were to elucidate the cellular and molecular effects of ANR1 in striatal neurons. Striatal neurons in vitro were employed. Importantly, the efficacy of ANR1 in prevention of excitotoxic cell death was assessed.

Preliminary data of the present study were reported in abstract form [30, 31].

\section{Experimental Procedures}

\section{Primary Cell Culture of Striatal Neurons}

In the present study, neonatal rats (postnatal day 1, SpragueDawley) were used. The handling of rats and all procedures that performed on them were approved in accordance with the Animals (Control of Experiments) Ordinance, Hong Kong, PR China, by the Committee on the Use of Human and Animal Subjects in Teaching and Research, Hong Kong Baptist University, and conformed to the Principles of Laboratory Animal Care [NIH publ. No. $86-23$, revised 1985]. The rats were sacrificed by decapitation and brain region of the neostriatum was dissected in a dissecting microscope [32]. The brain tissues were chopped using a razor blade in minimal essential medium (Gibco, BRL). The chopped tissues were then incubated in trypsin/EDTA solution with $1 \%$ penicillin-streptomycin (Gibco) and B27 supplement (Gibco) for $1 \mathrm{~h}$ at $37^{\circ} \mathrm{C}$ [32]. Agitation of the medium was performed every $15 \mathrm{~min}$. Single-cell suspension was obtained by dissociation of the tissues in Neurobasal medium with soybean trypsin inhibitor (Gibco) and DNase 1 (Boehringer Mannheim) for $30 \mathrm{~min}$ at $37^{\circ} \mathrm{C}$. Cell pellets were obtained by centrifugation (1,200 rpm for $5 \mathrm{~min})$. The pellets were washed and re-suspended in culture medium (Neurobasal medium, $1 \%$ penicillin-streptomycin, B27 supplement; Gibco; and 10\% fetal bovine serum; Sigma). The neurons were then plated on poly- $D$ lysine-coated 6-well plastic plates or on glass coverslips. The cultures were maintained at $37^{\circ} \mathrm{C}$ in $\mathrm{CO}_{2}$ incubator $\left(5 \% \mathrm{CO}_{2}\right)$. Cytosine arabinoside (10 $\mu M$, Fluka) was added to the culture 2 days after plating in order to inhibit the growth of glial cells [33]. Treatments on the cultures were conducted at 6 days in vitro [32].

\section{Oligonucleotide Treatments}

Oligonucleotide transcripts were designed on the basis of the known sequences of rat NR1 [26, 29]. All transcripts used in the present study contained 20 phosphorothiolated nucleotides and were purchased commercially (Gibco). ANR1 transcripts were proven by our laboratory to enable specific knockdown of NR1 protein expression in rat in vivo $[26,34]$. The sequences of the oligos were as follows: 5'-G CAG GTG CAT GGT GCT CAT G-3' (ANR1), 5'-C ATG AGC ACC ATG CAC CTG C-3' (NR1 sense: SNR1), 5'-A ACG TGA GCG TGG TCC TAG T-3' (randomized sequence based on the NR1 sequence: RNR1). ANR1, SNR1 and RNR1 were dissolved in $0.9 \%$ saline at a concentration of $2.5 \mathrm{mM}$ and stored at $-20^{\circ} \mathrm{C}$ prior to use. A single dose of 5, 20 or $100 \mu M$ oligos was added to the cultured striatal neurons at 6 days in vitro. The cultures were maintained at $37^{\circ} \mathrm{C}$ in a humidified $5 \% \mathrm{CO}_{2}$ atmosphere. Twenty-four hours after the treatment, the cells were harvested for reverse transcriptase-polymerase chain reaction (RTPCR) analysis. In addition, $30 \mathrm{~h}$ after the treatment, the cells were harvested for Western blot analysis, NMDA toxicity assay, or whole-cell patch clamp analysis.

\section{Reverse Transcriptase-Polymerase Chain Reaction}

All glass- and plastic-ware were treated with diethyl pyrocarbonate and autoclaved. TRIZOL Reagent (Gibco) was added to striatal neurons at $24 \mathrm{~h}$ after the oligo treatments. After $5 \mathrm{~min}$ incubation at room temperature, chloroform was added for phase separation. The upper aqueous phase was collected and the RNA was precipitated by mixing with isopropyl alcohol. The RNA pellet was washed once with $75 \%$ ethanol and was air-dried. It was finally re-dissolved in RNase-free water. $\mathrm{A}_{260} / \mathrm{A}_{280}$ ratios were between 1.6 and 1.8.

Semiquantitative RT-PCR was conducted as described previously using the housekeeping gene GAPDH as an internal standard [26, 27, 35, 36]. RT-PCR was performed using Ready-To-Go RTPCR beads (Amersham Pharmacia Biotech) and was calibrated using GAPDH and NR1, NR2A, NR2B, NR2C or NR2D primer pairs (see below). Different amplification cycles were used to allow detection of the amplified products while keeping amplification for these genes in the log phase (NR1, 33 cycles; NR2A, 47 cycles; NR2B, 31 cycles; NR2C, 48 cycles; N2D, 43 cycles; GADPH, 26 cycles; results of the NR1 control experiment are shown in fig. 1).

Total RNA was diluted to $1 \mu \mathrm{g} / \mu \mathrm{l}$ in RNase-free water, mixed with $0.5 \mu \mathrm{g}$ of $\mathrm{pd}(\mathrm{N})_{6}$ and $47 \mu \mathrm{l}$ of RNase-free water to a final volume of $49 \mu \mathrm{l}$ in a reaction tube containing RT-PCR beads. The reaction was incubated at $42^{\circ} \mathrm{C}$ for $30 \mathrm{~min}$, followed by $95^{\circ} \mathrm{C}$ for 
5 min to inactivate the RT and to completely denature the template. Gene-specific primer sets were constructed as previously described [26, 27, 37, 38] (NR1: 5'-AACCTGCAGAACCGCAAG-3' and 5'GCTTGATGAGCAGGTCTATGC-3'; NR2A: 5'-TCCATTCTTCTGTCATCCTGC-3' and 5'-AAGACCGTCTCTCACTCTTGC-3'; NR2B: 5'-TGCACAATTACTCCTCGACG-3' and 5'TCCGATTCTTCTTCTGAGCC-3'; NR2C: 5'-TTGAGGACAACGTGGACACC-3' and 5'-TCCAGTCGTATTCCTCCAGC-3'; NR2D: 5'-GCACTTGCATCAGAGACTCG-3' and 5'-CTCACCAATCATGCCATTCC-3'). One of the primer sets was added to give a final volume of $50 \mu \mathrm{l}$. Reactions were run for the optimal cycles with $55^{\circ} \mathrm{C}$ annealing cycle $(1 \mathrm{~min}), 72^{\circ} \mathrm{C}$ extension cycle ( $1 \mathrm{~min}$ ), and a $95^{\circ} \mathrm{C}$ denaturing cycle $(50 \mathrm{~s})$. The GAPDH (5'-ATGGTGAAGGTCGGTGTGAAC-3' and 5'-GCTGACAATCTTGAGGGAGT-3') primer set [35] was added into the reaction according to its corresponding pre-calibrated cycle number. Control amplifications were done either without RT or without RNA. Amplification from primers, NR1, NR2A, NR2B, NR2D and GAPDH produces a fragment of 333, 224, 222, 224 and $437 \mathrm{bp}$ in length, respectively [26, 27, 37, 38]. Images of the gels after RT-PCR analyses were digitally captured by a gel documentation system (Ultra Violet Products C-80). Fluorescence intensity of each band was then semiquantified by an image analyzing software (Metamorph, Universal Imaging, Downingtown, Pa., USA). The changes of intensity of NR1 mRNA after the ODN treatments were normalized using the intensity obtained in the GAPDH bands and the ratios were expressed as mean $\pm \operatorname{SEM}[27,37]$. Data obtained from at least three separate treatments were averaged and compared with other groups by ANOVA with Duncan's multiple range tests.

\section{Western Blot Analysis}

Western blot analysis was performed in accordance with a previous study [39]. Thirty hours after the oligo treatments, neurons in culture were washed $(3 \times$ PBS) and lyzed in buffer (in $\mathrm{m} M$ : sucrose 250 , imidazole/ $\mathrm{HCl} 50$, sodium EDTA 2 and $\beta$-mercaptoethanol, $\mathrm{pH}$ 7.2). The lysate was collected and centrifuged at $14,000 \mathrm{~g}$ for $15 \mathrm{~min}$. The supernatant was stored at $-70^{\circ} \mathrm{C}$. The quantity of proteins in the lysate was determined using a commercially available kit (Biorad Protein Assay Kit). Proteins (100 $\mu \mathrm{g} / \mathrm{well})$ were submitted to SDS-polyacrylamide gel electrophoresis and electroblotted onto nitrocellose membranes using a commercially available system (Bio-Rad Mini-protean 3 and mini trans-blot electrophoretic transfer for cell). The membranes were subjected to Western blot analysis. Total NR1 proteins were revealed by NR1 specific primary antibodies (rabbit polyclonal anti-NR1, $0.05 \mu \mathrm{g} /$ $\mathrm{ml}$ in Tris-buffered saline supplied with $2 \%$ nonfat skim milk, $0.05 \mathrm{M}, \mathrm{pH}$ 7.4 [TBS], Chemicon; or mouse monoclonal anti-NR1, $1 \mu \mathrm{g} / \mathrm{ml}$ in TBS, Upstate Biotechnology). In addition, two phosphorylated forms of NR1 proteins were also revealed using specific antibodies (rabbit polyclonal anti-phospho-ser896-NR1, $1 \mu \mathrm{g} /$ $\mathrm{ml}$ in TBS, and rabbit polyclonal anti-phospho-ser897-NR1, $1 \mu \mathrm{g} /$ $\mathrm{ml}$ in TBS, all from Upstate Biotechnology). In control experiments, proteins from striatal neurons were treated with 500 units of lambda protein phosphatase in phosphatase reaction buffer (from Upstate Biotechnology) for $4 \mathrm{~h}$ at $30^{\circ} \mathrm{C}$ prior to the phosphorylated NR1-specific antibody treatments. The membranes were incubated in primary antibodies for $2 \mathrm{~h}$ at room temperature. The membranes were then incubated in appropriate secondary antibodies (horseradish peroxidase-conjugated goat anti-rabbit IgG or goat anti-mouse IgG, Santa Cruz, 1:5,000 in TBS with 2\% non-

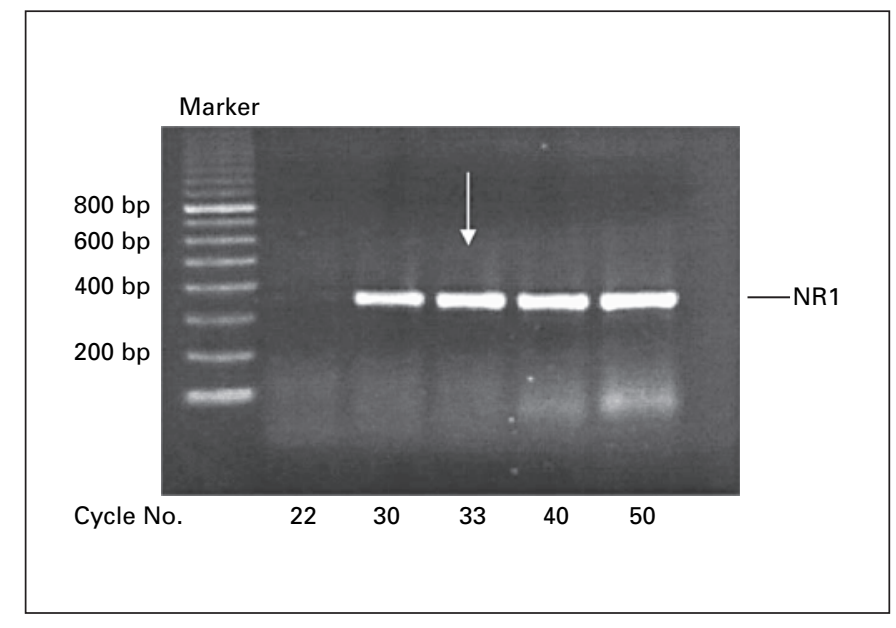

Fig. 1. Amplification of NR1 subunit from striatal neurons with different PCR cycles is shown. The optimum cycle is shown here as 33 cycles (indicated by an arrow).

fat skim milk) for $1 \mathrm{~h}$ at room temperature. Bands in the membranes were visualized using chemiluminescence detection (ECL Western blotting detection reagents; Amersham Pharmacia Biotech; the above procedure was performed in accordance with the supplier). Images of the bands were developed on films and captured by a computer with a scanner. Optical density of each band was then semiquantified by software (Metamorph) and statistically analyzed by one-way ANOVA with Duncan's multiple range tests.

\section{Double Immunofluorescence}

Thirty hours after oligo treatments, striatal neurons were washed $(3 \times$ phosphate-buffered saline [PBS], $\mathrm{pH} 7.4)$ prior to immunofluorescence. Immunoreactivity for NR1 plus glutamic acid decarboxylase 67 (GAD; a specific neurochemical marker for GABAergic striatal neurons) was revealed in a single reaction for comparison. Double immunofluorescence was performed as previously described [32]. Briefly, neurons were incubated in a mixture of primary antibodies, namely, NR1 (rabbit polyclonal; $0.5-1.0 \mu \mathrm{g} / \mathrm{ml}$ in PBS supplemented with $2 \%$ NGS and $0.1 \%$ Triton X-100 [PBSTriton]; Chemicon) with GAD (mouse monoclonal; 1:2,000 in PBS-Triton; Chemicon) for $2 \mathrm{~h}$ at room temperature. The neurons were then washed $(3 \times$ PBS $)$ and incubated with a mixture of secondary antibodies for $1 \mathrm{~h}$ at room temperature. Goat anti-rabbit IgG conjugated with Alexa 488 (1:200 in PBS-Triton, Molecular Probes) and goat anti-mouse IgG conjugated with cy5 (1:200 in PBS-Triton, Chemicon) were used. The neurons were then washed $(3 \times$ PBS $)$ and mounted on glass slides with mounting medium (Vectashield, Vector Labs). The neurons were then observed in a laser scan confocal microscope (Zeiss LSM 510; excitation at 488 and $633 \mathrm{~nm}$ ). Digital images of the double-labeled neurons showing immunoreactivity for NR1 and GAD were captured under the same parameters in the confocal microscope. 
Fig. 2. Co-amplification of NR1, NR2 subunits and GAPDH obtained from striatal neurons treated with NR1 antisense oligos (ANR1), NR1 sense oligos (SNR1), NR1 random oligos (RNR1) and control. A A band of NR1 PCR product of $333 \mathrm{bp}$ is observed in each of the four groups. The level of NR1 mRNA is only seen to be reduced after ANR1 treatment when compared to the other three groups (indicated by asterisk). Similar levels of NR1 mRNA are found in the sense NR1-, random NR1-treated striatal neurons and in control striatal neurons. B-D The levels of NR2A (224 bp), NR2B(222 bp) and NR2D (224bp) mRNAs remain the same in all four groups of striatal neurons.

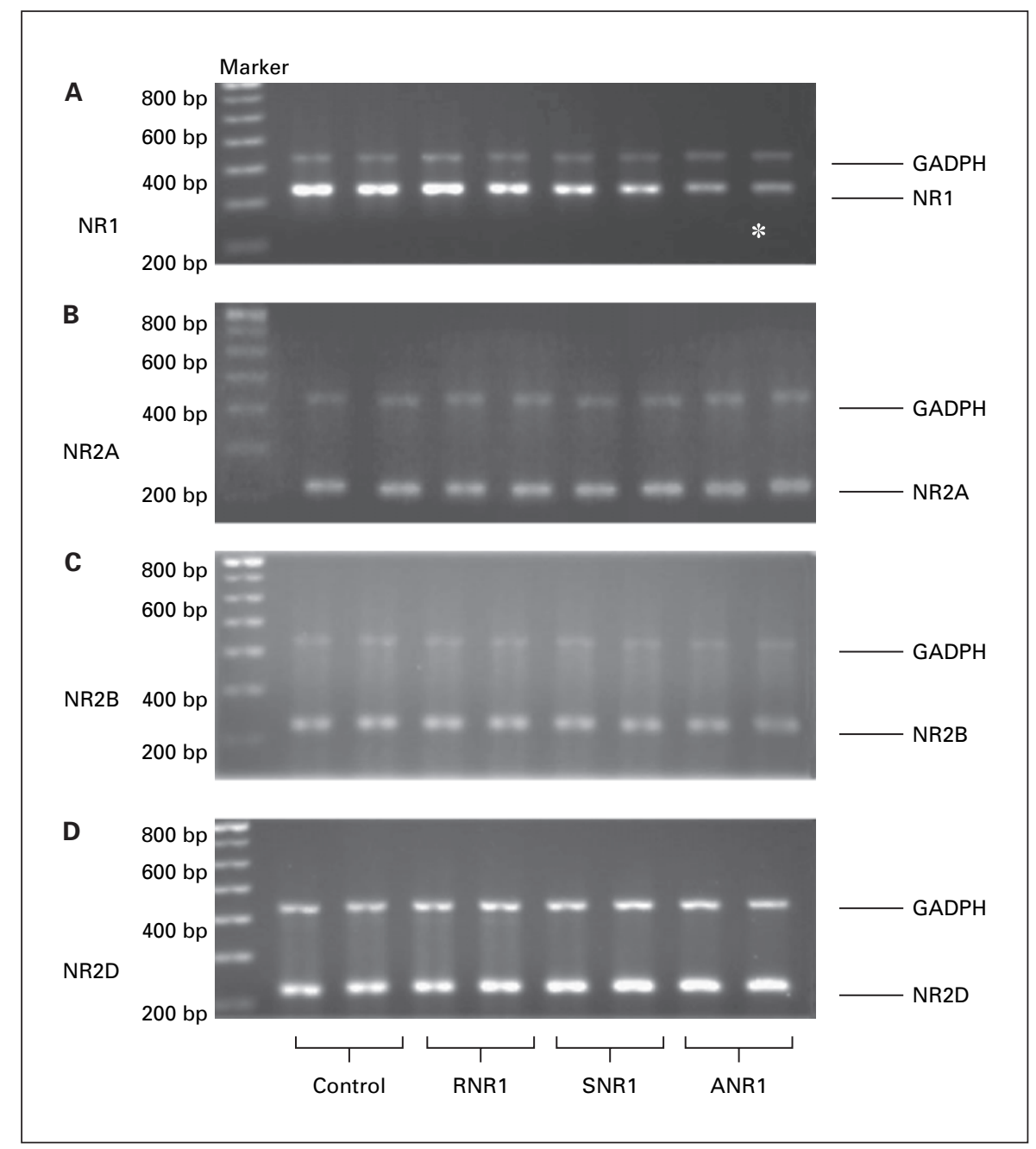

\section{Control for Immunocytochemistry}

Control experiments for double immunofluorescence were carried out by omitting either primary or secondary antibody solutions in the above reaction sequence. The cells were then observed in the fluorescence microscope or in the confocal microscope [32].

\section{Whole-Cell Recordings}

Whole-cell patch clamp recording experiments were performed in accordance to a previous study [32]. Striatal neurons in primary cell culture were cultured on poly- $D$-lysine-coated coverslips. The coverslips with neurons were transferred to a small-volume recording chamber that was mounted on an upright microscope. The neurons were continuously superfused at $2.5-3 \mathrm{ml} / \mathrm{min}$ with artificial cerebrospinal fluid (ACSF) of the following composition (in $\mathrm{m} M$ ): $\mathrm{NaCl} 125, \mathrm{KCl} 2.0, \mathrm{CaCl}_{2} 2.5, \mathrm{KH}_{2} \mathrm{PO}_{4} 1.2$, glucose 11 and $\mathrm{NaHCO}_{3} 26$. The ACSF was continuously bubbled with $95 \% \mathrm{O}_{2}$ and $5 \% \mathrm{CO}_{2}$ and maintained at $35 \pm 1{ }^{\circ} \mathrm{C}$. Whole-cell patch-clamp recordings were obtained from striatal neurons at $30 \mathrm{~h}$ after ODN treatments. The pipettes typically had a resistance of 3-4 M $\Omega$ when filled with an internal solution of the following composition (in $\mathrm{m} M$ ): K-gluconate 140, EGTA 1.0, $\mathrm{MgCl}_{2} 2.0, \mathrm{Na}_{2} \mathrm{ATP} 2.0$, Tris GTP 0.4, HEPES 10, with pH adjusted to 7.25 7.30. Application of NMDA was achieved by switching the control ACSF to one containing a known concentration of the drug. NMDA-induced currents were measured at a holding potential of $-60 \mathrm{mV}$. The peak inward currents were expressed as mean \pm SEM and compared statistically by one-way ANOVA with Tukey's post hoc tests. In some experiments, biocytin (1\%) was included in the internal solution to label the recorded neuron to facilitate identification during subsequent immunostaining for GAD.

\section{NMDA Toxicity Assay}

Thirty hours after the oligo treatments, the striatal neurons were subjected to NMDA toxicity experiments as described previously [33]. Neurons were washed in glutamate-free Locke's solution (in $\mathrm{m} M: \mathrm{NaCl} 128, \mathrm{KCl} 5, \mathrm{MgCl}_{2}$ 1.2, $\mathrm{CaCl}_{2}$ 2.7, $\mathrm{Na}_{2} \mathrm{HPO}_{4}$ 1, HEPES 5 and glucose $10 ; \mathrm{pH} \mathrm{7.4)} \mathrm{for} 10 \mathrm{~min}$ at $37^{\circ} \mathrm{C}$. Neurons were then incubated with $500 \mu M$ NMDA, 1,000 $\mu M$ NMDA, or $500 \mu M$ NMDA plus $1 \mathrm{~m} M$ DL-2-amino-5-phosphonovalerate (DL-APV, Tocris) in $\mathrm{Mg}^{2+}$-free Locke's solution in the presence of $3 \mu M$ gly- 
Table 1. Statistical analysis of the level of fluorescence of the bands after RT-PCR (ratios between the NR and GAPDH bands)

\begin{tabular}{|c|c|c|c|c|}
\hline PCR product & Control & RNR1 treatment & SNR1 treatment & ANR1 treatment \\
\hline NR1 & $1.53 \pm 0.06$ & $1.51 \pm 0.03$ & $1.33 \pm 0.07$ & $\begin{array}{r}0.82 \pm 0.05^{* * *} \\
{[-43.16 \pm 2.57 \%]}\end{array}$ \\
\hline NR2A & $1.07 \pm 0.03$ & $1.12 \pm 0.02$ & $1.12 \pm 0.07$ & $1.08 \pm 0.01$ \\
\hline NR2B & $1.37 \pm 0.08$ & $1.34 \pm 0.07$ & $1.32 \pm 0.07$ & $1.29 \pm 0.06$ \\
\hline NR2D & $1.26 \pm 0.05$ & $1.25 \pm 0.07$ & $1.27 \pm 0.05$ & $1.21 \pm 0.05$ \\
\hline
\end{tabular}

Means \pm SEMs are shown. Statistical analysis was performed using one-way ANOVA with Duncan's multiple range tests. $* * * \mathrm{p}<0.001$. cine. The neurons were rinsed with Locke's solution and incubated in culture medium for $24 \mathrm{~h}$ at $37^{\circ} \mathrm{C}$. Control experiments were performed in neurons of the same culture periods using the same treatments of the $\mathrm{Mg}^{2+}$-free Locke's solution without NMDA.

After treatments, digital images of neurons were captured by a digital camera in the microscope. Percentage of cell death in cultures after exposure to NMDA and in control experiments was assessed by determination of the enzymatic activity of lactate dehydrogenase (LDH) in the culture medium using a commercially available cytotoxicity detection kit (cytotoxicity detection kit [LDH], Roche Molecular Biochemicals). Protocols were employed in accordance to the supplier's information. The percentage of cell death was estimated by measuring the optical density of the tested samples using a spectrophotometer (iEMS analyzer, Labsystems). The percentage of cell death in those cells treated with NMDA was then normalized by the values of the control experiments. All data are presented as means \pm SEM and statistical analyses were performed using one-way ANOVA with Duncan's multiple range tests.

\section{Results}

\section{Effects of ANR1 Treatments on Expression of NMDA} Receptor $m R N A s$

Data were obtained from twenty four separate RTPCR experiments. No detectable level of NR2C mRNA was found in the striatal neurons in culture (data not shown) and this was consistent to our previous report [32]. Six hours after treatments using a single dose of $5 \mu M$ of ANR1, RT-PCR showed that there were no changes in the mRNA levels of the NR1, NR2A, 2B and 2D mRNAs when compared to the SNR1-treated, RNR1treated or controls (data not shown).

Subsequently, $24 \mathrm{~h}$ after the ANR 1 application, there was a pronounced reduction in the intensity of NR1 mRNA (fig. 2A). Statistical analysis of the PCR products indicated that this was a significant decrease (table 1). Treatments with SNR1 and RNR1 did not affect the NR1 mRNA levels in the striatal neurons (fig. 2A; table 1). Similarly, treatments with 20 and $100 \mu M$ of ANR1 re- sults in similar degree of reduction of NR1 mRNA levels (data not shown).

In addition, same as the $6 \mathrm{~h}$ treatments, no modulation in the levels of NR2A, NR2B and NR2D mRNAs in the ANR1-treated striatal neurons was found after $24 \mathrm{~h}$ treatment (fig. 2B-D; table 1).

\section{Effects of ANR1 Treatments on Expression of NRI Proteins}

Data were obtained from 18 separate Western blotting experiments. A reduction in NR1 protein was found in the striatal neurons treated with $5 \mu M$ ANR1 (fig. 3A). No change in the NR1 protein expression was found in the neurons treated with RNR1 or SNR1 (fig. 3A). Statistical analyses revealed that significant reductions $(-51.85$ $\pm 0.73 \%$ ) were found in the striatal neurons treated with 5 and $20 \mu M$ of ANR1 (fig. 3B). Treatments with $100 \mu M$ of ANR1 also resulted in similar reduction of NR1 protein expression (data not shown).

\section{Effects of ANR1 Treatments on Phosphorylation of NR1 Proteins}

Data were obtained from fifteen separate Western blotting experiments. In the control experiments, bands of phosphorylated NR1 proteins were eliminated after treatment with phosphatase (fig. 4A). Similar to the above results, after treatment with $5 \mu M$ of ANR1, a significant reduction of NR1 proteins was seen (fig. 4B). However, levels of two phosphorylated forms of NR1 proteins, i.e. NR1 proteins phosphorylated at serine 896 and 897 residues, were not modulated after the ANR1 treatments (fig. 4B-E). Similar results were found after treatments with 20 and $100 \mu M$ of ANR1 (data not shown).

\section{Effects of ANR1 Treatments on Patterns of NRI Immunoreactivity}

Data were obtained from 20 experiments. Double immunofluorescence revealed that most of the striatal neu- 
Fig. 3. Western blotting analyses of the levels of NR1 proteins in striatal neurons treated with NR1 antisense oligos (ANR1), NR1 sense oligos (SNR1), NR1 random oligos (RNR1) and in control. A A single NR1immunoreactive band of about $120 \mathrm{kDa}$ is observed in each of the four groups. Reductions in the level of NR1 protein are observed only after treatment with ANR1 (5 and $20 \mu M$ ). Similar levels of NR1 protein are found in the SNR1 and RNR1 treatments and in the control. B Statistical analyses show that significant reductions in the expression of NR1 proteins are observed only after ANR1 treatments ( 5 and $20 \mu M$ ). Means \pm SEM are shown. ${ }^{* * *} \mathrm{p}<$ 0.001 .

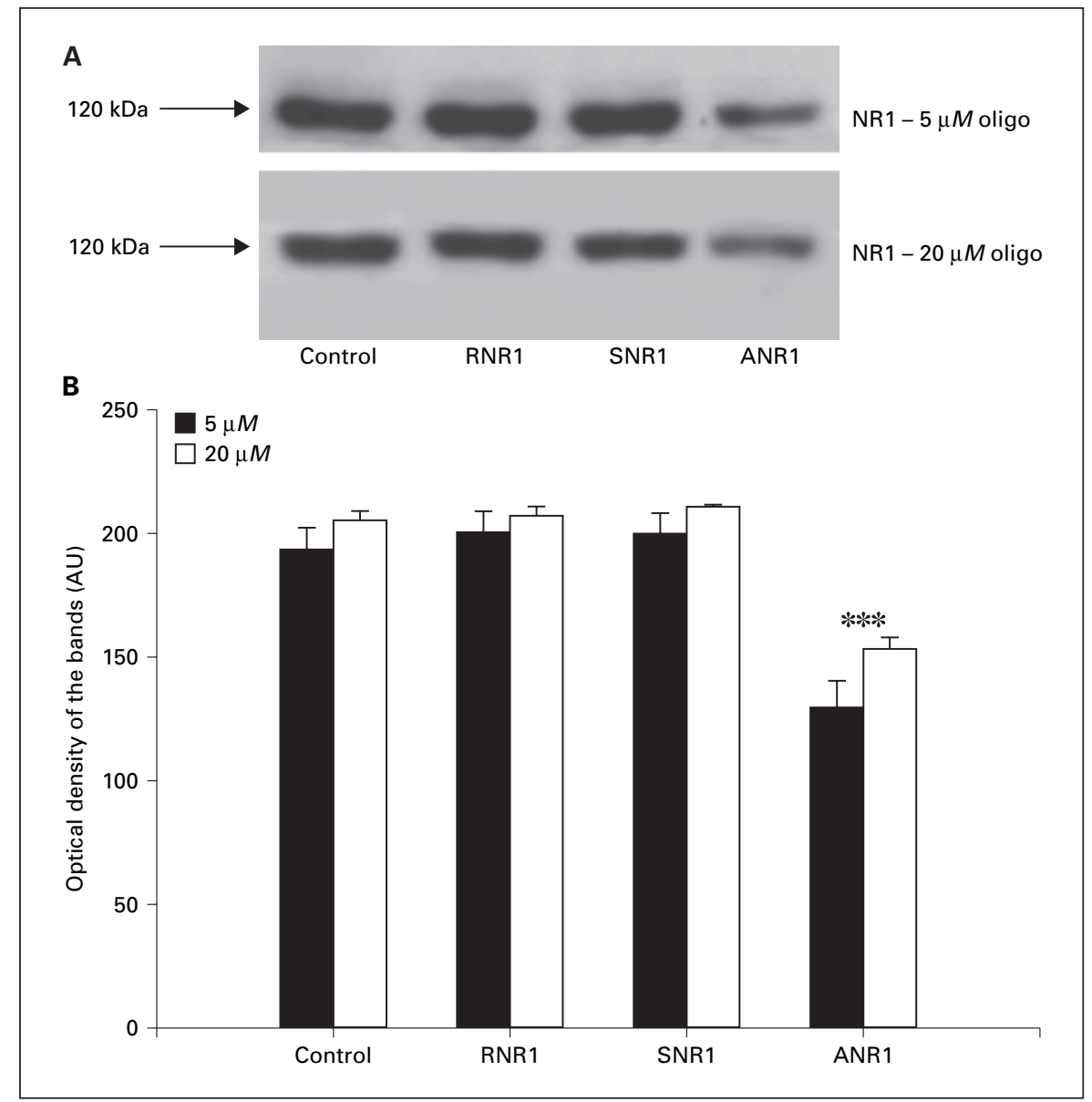

rons displayed immunoreactivity for GAD (fig. 5). They were therefore presumed to be GABAergic neurons. No difference in the patterns of distribution of NR1 immunoreactivity was observed after ANR1 treatments (fig. 5).

\section{Effects of ANR1 Treatments on Physiology of NMDA}

\section{Receptors}

Data were obtained from recording of 36 striatal neurons. The neurons were observed by a DIC-infrared camera in the light microscope (fig. 6A). The neurons were injected with biocytin and were identified by fluorescence microscopy (fig. 6B). Subsequently, GABAergic striatal neurons were confirmed by the display of GAD immunoreactivity (fig. 6C).

In the GAD-positive striatal neurons with ANR1 treatments, NMDA-induced peak inward current was observed to be over $20 \mathrm{pA}$ (fig. 7A, B). After $5 \mu M$ ANR1 treatment, no statistical difference in the NMDA-induced peak inward currents was observed between the control and the treatment neurons (fig. 7B). However, a significant reduction in NMDA-induced peak inward currents was observed in the striatal neurons treated with 20 or $100 \mu M$ ANR1 (fig. 7B).

Fig. 4. Western blotting analyses of the levels of NR 1 proteins and two phosphorylated forms of NR1 proteins at serine 896 ( $p$ NR1 s896) and 897 ( $p$ NR1 s897) residues in striatal neurons treated with NR1 antisense oligos (ANR1), NR1 sense oligos (SNR1), NR1 random oligos (RNR1) and in control. A Results of experiments before and after phosphatase pretreatments are shown. After phosphatase pre-treatments, bands of the phosphorylated NR1 proteins were abolished. B As shown in figure 2, a reduction of NR1 protein expression is observed only after ANR1 treatment (indicated by an arrow). No change in expressions of the two phosphorylated forms of NR1 proteins at serine 896 and 897 residues is found. C-E Statistical analyses reveal that a significant reduction is seen in total NR1 proteins. No significant change of the two phosphorylated forms of NR1 proteins is found. $* * * \mathrm{p}<0.001$. 


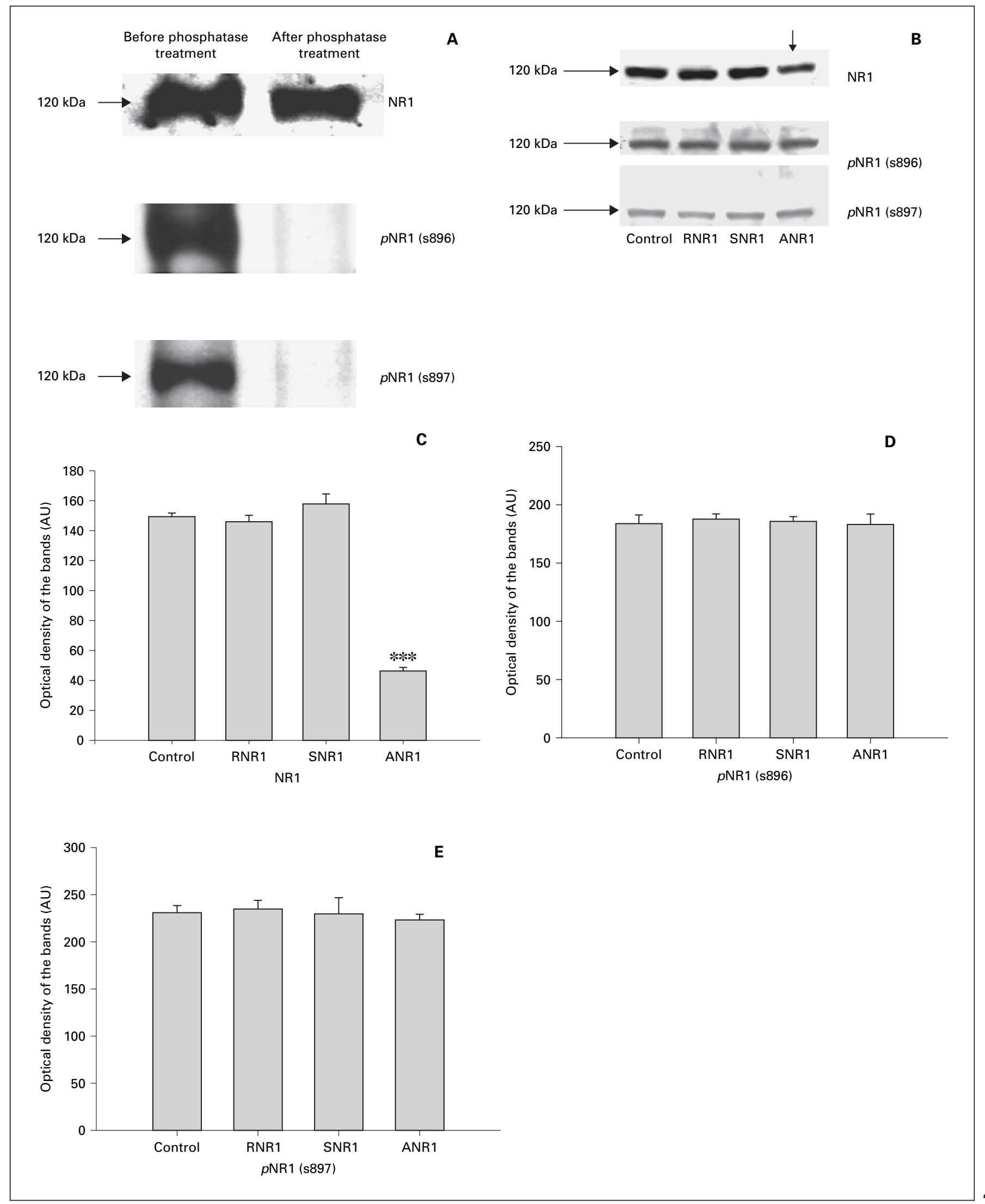

NR1 Gene Knockdown Offers

Neurosignals 2005;14:303-316 
Fig. 5. Results of immunofluorescence analyses are shown. In glutamic acid decarboxylase (GAD)-immunoreactive striatal neurons (A, C, E), when compared with the control (B), NR1 antisense (ANR1) treatments with two concentrations $(5 \mu M$ in $\mathbf{D} ; 20 \mu M$ in $\mathbf{F})$ result in no change in pattern of distribution of NR1 immunoreactivity. Scale $\operatorname{bar}($ in $\mathbf{F}$, for all micrographs) $=50 \mu \mathrm{m}$. Fig. 6. A Differential interference contrast image of patched striatal neuron is shown. B The same neuron shown in $\mathbf{A}$ is revealed by the presence of biocytin (revealed by using avidin-rhodamine). c The same patched striatal neurons are then immunostained to reveal immunoreactivity for glutamic acid decarboxylase (GAD) to confirm the identity of GABAergic neurons in striatal culture. Scale bar (in C; for all micrographs) = $50 \mu \mathrm{m}$.
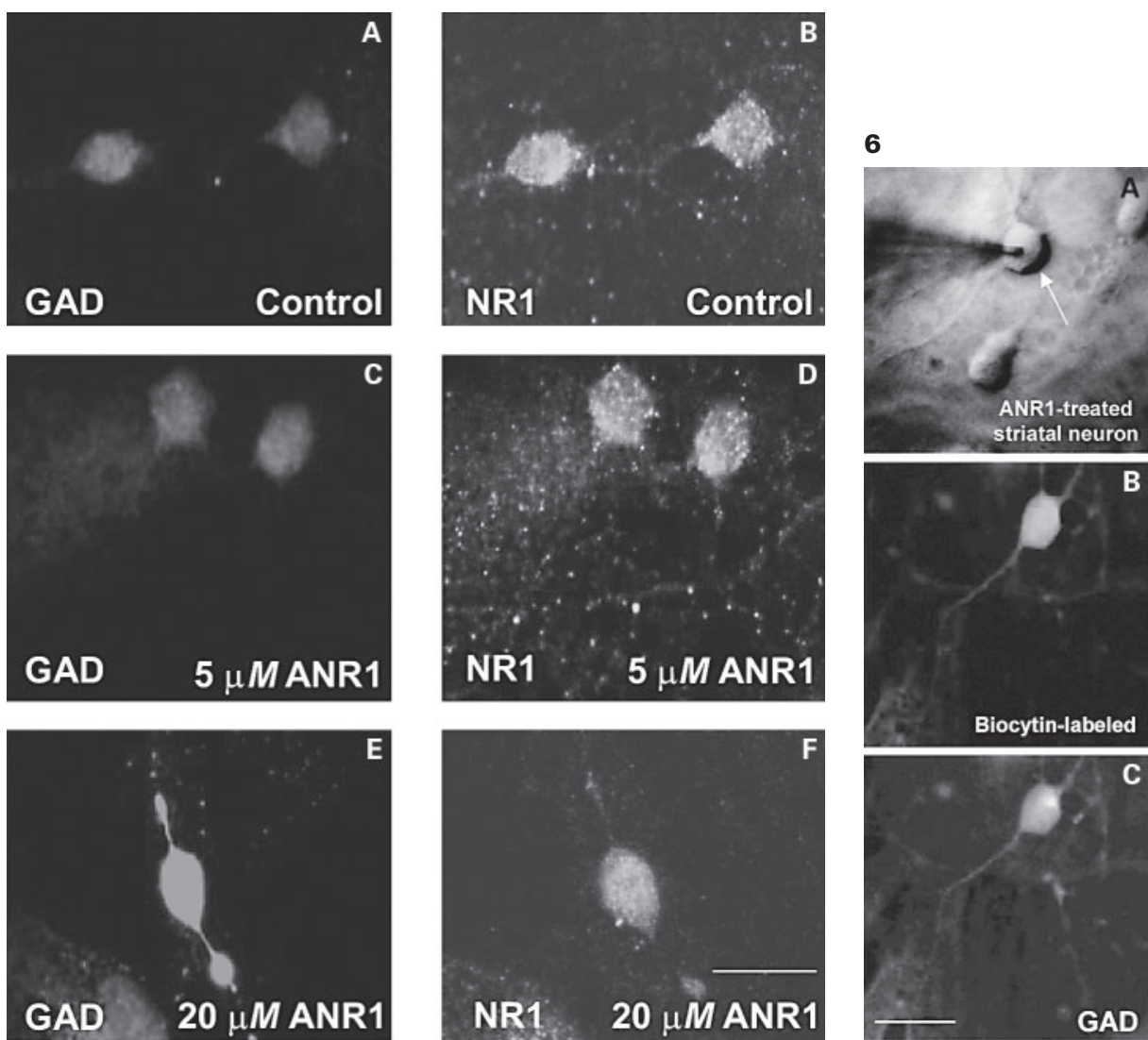

\section{Effects of ANR1 Treatments on NMDA-Induced \\ Excitotoxic Cell Death}

Data were obtained from 21 experiments. No observable cell death was found in striatal neurons treated with ANR1 (data not shown). Addition of $500 \mu M$ of NMDA induced a high degree of cell death in the cultured striatal neurons (fig. 8A). A significant reduction of NMDAinduced cell death was observed when the cultures were treated with NMDA together with DL-APV (fig. 8B). High degree of cell death was observed in cultures cotreated with NMDA together with $5 \mu M$ (fig. 8C) or $20 \mu M$ (fig. 8D) of RNR1. Similarly, a high degree of cell death was also observed in cultures co-treated with NMDA and $5 \mu M$ (fig. 8E) or $20 \mu M$ (fig. 8F) of SNR1. In contrast, similar to DL-APV, neuroprotective effects were seen in cultures treated with NMDA together with $5 \mu M$ (fig. 8G) and $20 \mu M$ (fig. 8H) of ANR1. Statistical analyses revealed that significant reductions in NMDAinduced excitotoxicity were found only in co-treatments of NMDA with L-APV or 5 or $20 \mu M$ of ANR1 (fig. 8I).

\section{Discussion}

The results of the present study indicate that ANR 1 is a potent neuroprotective agent against NMDA-induced excitotoxic cell death in striatal neurons in vitro. The efficacy of ANR1 is also shown by the present results as one single dose of ANR1 is effective to reduce significantly both NR1 mRNA and protein expressions. The NMDAinduced inward currents are thus reduced by the application of ANR1. These findings as a whole indicate that ANR1 has potential therapeutic applications for neurodegenerative diseases.

\section{ANRI Is a Specific and Nontoxic Agent}

The first important finding here is that ANR1 is specific for reducing the expressions of NR $1 \mathrm{mRNA}$ and protein. The present results have demonstrated the specificity of ANR1 as SNR1 and RNR1 results in no reduction of NR1 protein expression. There is also no change in expression of NR2 subunits after ANR1 treatments. These findings, however, do not preclude the possibility that ANR1 may have effects on other neurotransmitter systems. 


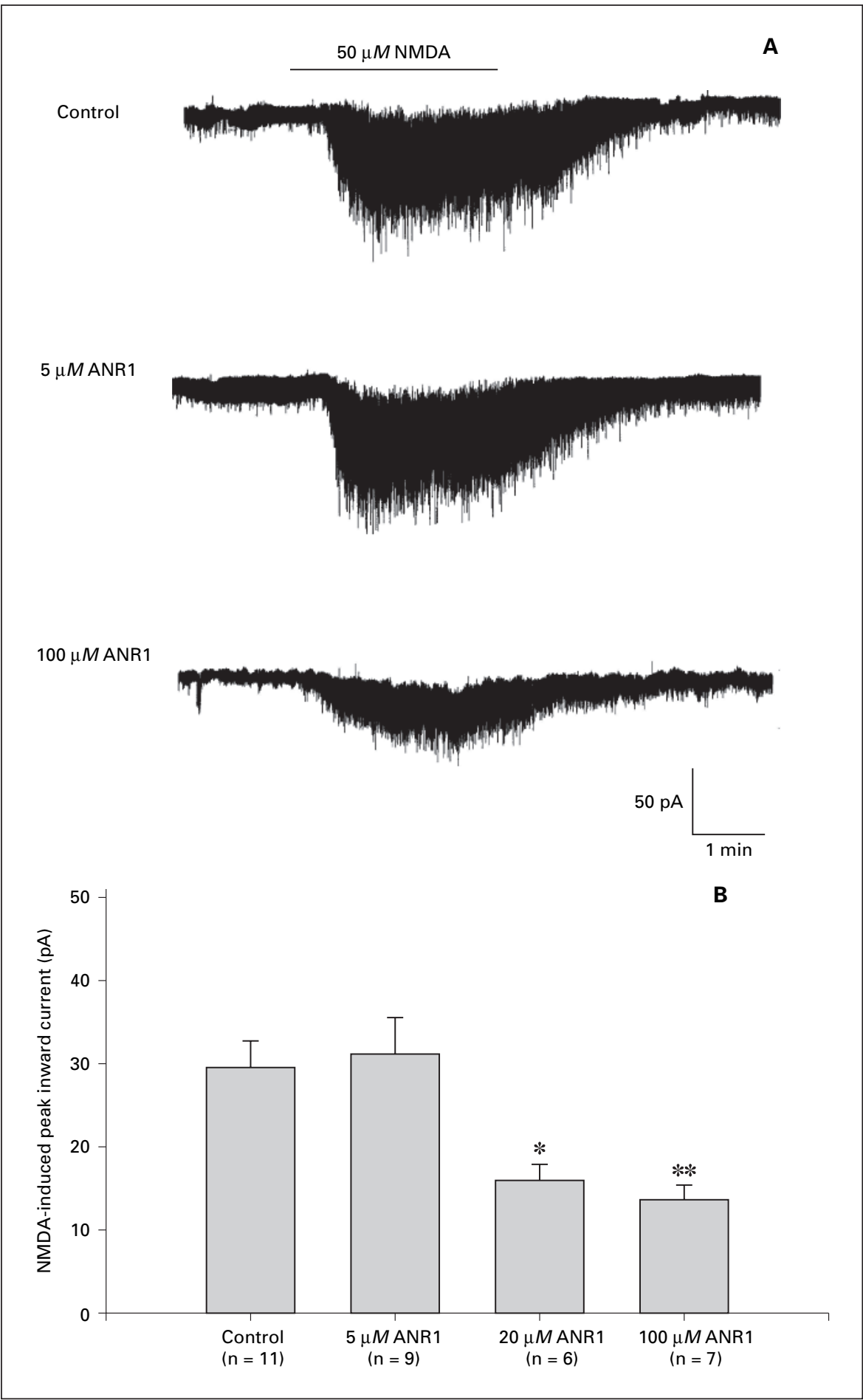

Fig. 7. A Typical traces showing the wholecell membrane current induced by $50 \mu M$ NMDA in a striatal neuron. No change in current is observed after application of $5 \mu M$ of NR1 antisense oligos (ANR1). In contrast, a reduction of the whole-cell membrane current is observed after the application of $100 \mu M$ of ANR1. B Statistical analyses indicate that the whole-cell membrane currents induced by $50 \mu M$ NMDA in the striatal neurons treated with 20 or $100 \mu M$ of ANR 1 are significantly reduced. $* \mathrm{p}<0.05 ; * * \mathrm{p}<0.01$.

Previous reports demonstrate that intraparenchymal applications of ANR1 in the neostriatum result in modulations in motor behaviors of rats [26, 29] and exert an amelioration of motor symptoms in parkinsonian rats
[28]. Compared to the previous in vivo studies [26, 27, 29], an equivalent amount of ANR 1 has been applied to striatal neurons in culture. The present results thus extend our previous in vivo observations $[26,28]$ that ANR 1 

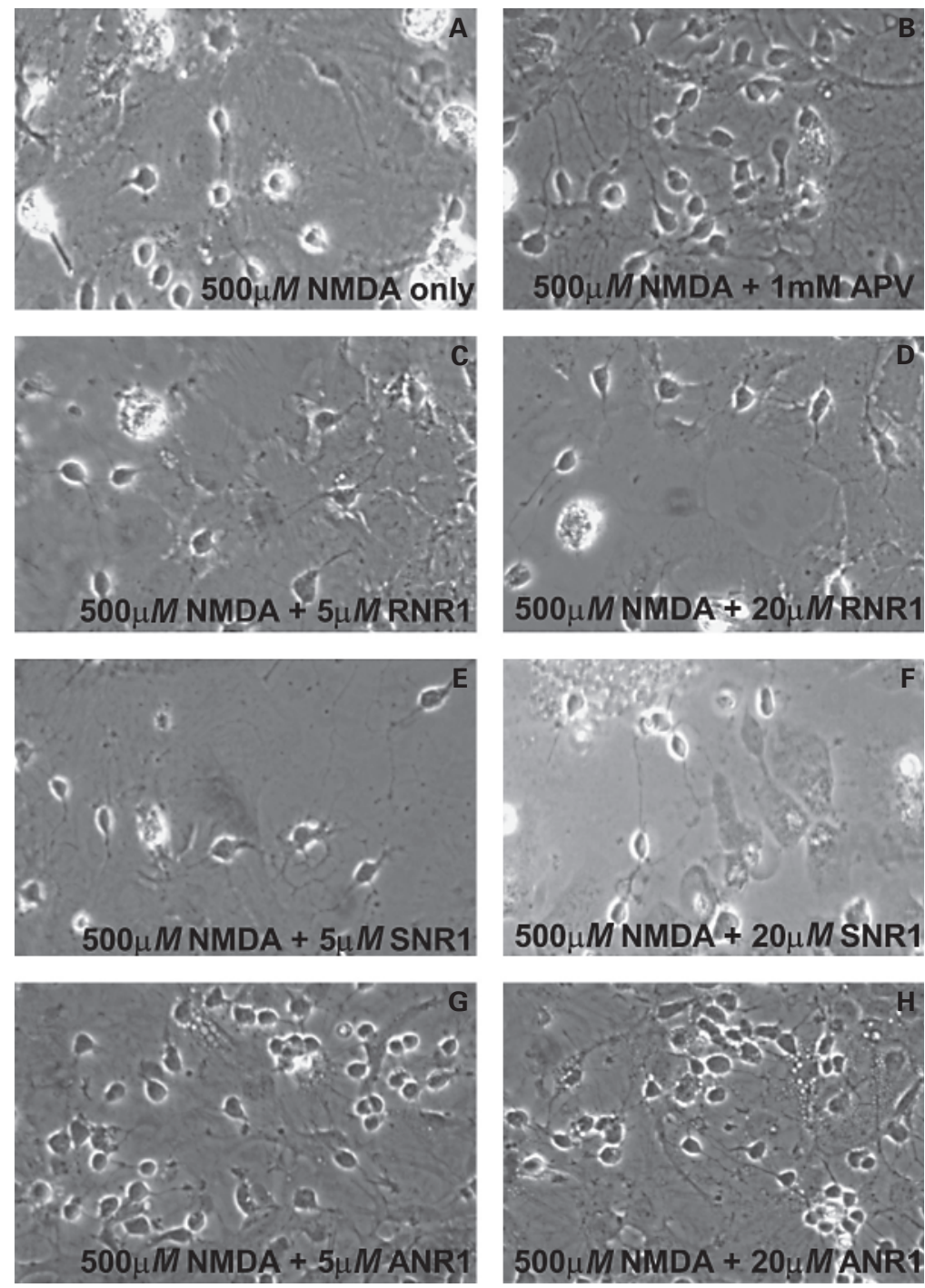

Fig. 8. Neuroprotective effects of NR1 antisense oligos (ANR1) are shown. In primary cell culture, there is only a low number of striatal neurons which can survive after the treatment of $500 \mu M$ of NMDA (A). The number of survived striatal neurons is seen to increase after cotreatment using $500 \mu M$ of NMDA with $1 \mathrm{~m} M$ of DLAPV (B). Co-treatments of NMDA with NR1 random oligos (RNR1: 5 or $20 \mu M$, C-D) or NR1 sense oligos (SNR1: 5 or $20 \mu M$, E-F) do not increase the number of survived striatal neurons. In contrast, the numbers of survived striatal neurons are seen to increase after cotreatments of NMDA with ANR1 ( 5 or $20 \mu M$, G-H). Statistical analyses reveal that significant reductions in NMDA-induced toxicity are only found in striatal neurons treated with ANR1 (5 and $20 \mu M$ ) and DL-APV (I). $* \mathrm{p}<0.05$.

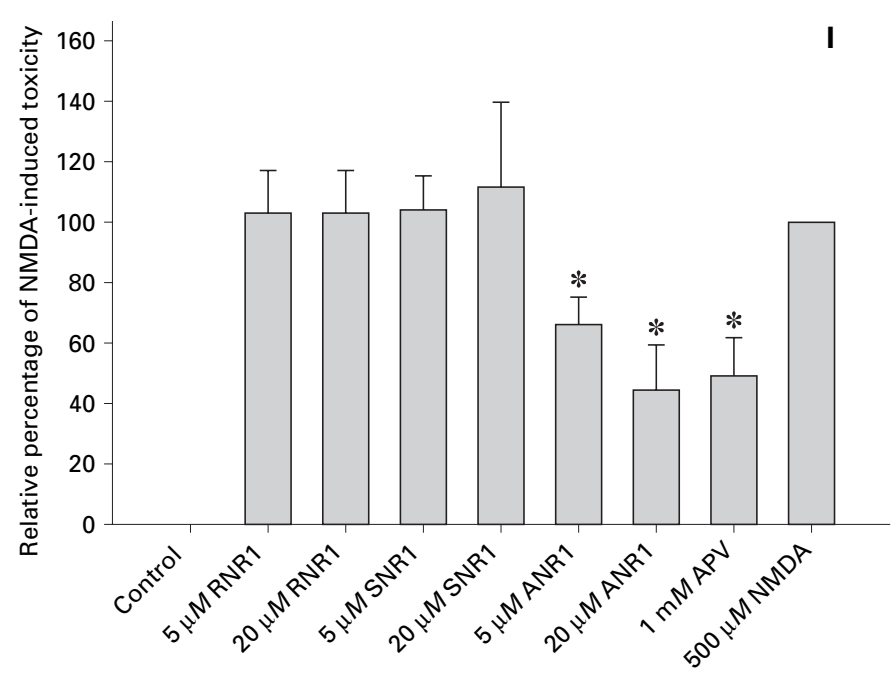


is capable to reduce the amount of NR 1 mRNAs, and importantly proteins in cultured striatal neurons up to the extent of around 30\% reduction. ANR1 is found to exert its actions directly on striatal neurons and is thus capable of inducing robust modulations in motor behaviors.

The second important finding is that ANR1 is nontoxic to striatal neurons as shown by the present NMDA toxicity assays and patch clamp analysis. Toxic effects of ANR1, if any, are far more difficult to observe in previous in vivo studies $[26,28]$. The present results thus demonstrate that application of ANR1 up to $100 \mu M$ do not induce neuronal cell death.

In addition, immunofluorescence also demonstrated that there is no change in the pattern of distribution of NR1 immunoreactivity. This observation reflects that the aftermath effect of ANR1 does not modulate intracellular distribution of the NR1 proteins as there is less effect of ANR1 in the phosphorylation of NR1 at serine residues (see below), in which phosphorylation of NR1 is related to the subcellular distribution of NMDA receptors [4042]. ANR1 may therefore affect the dynamic metabolism of NR1 protein synthesis.

\section{ANR1 Directly Modulates NMDA Receptor Physiology}

NR1 is the principal subunit of a functional NMDA receptor $[10,12,14]$. NMDA channels are mixed ion channel $[15,43,44]$. Two major ions that can go through the NMDA channels are $\mathrm{Na}^{+}$and $\mathrm{Ca}^{2+}$ ions $[15,43,44]$.

A reduction of NMDA-mediated inward current in general reflects a reduction in $\mathrm{Na}^{+}$influx in the striatal neurons through the NMDA channels. These observations have raised an interesting point. The present RTPCR and Western blot analyses have revealed that different concentrations of ANR1 employed (low concentration: $5 \mu M$; high concentration: $20-100 \mu M$ ) have similar potency in reduction of NR1 mRNA and protein expressions. The effects of different concentrations of ANR1 on the NMDA channel activities, in theory, should remain the same. Interestingly, it seems to be not the case in $\mathrm{Na}^{+}$ influx through the NMDA channel as indicated by wholecell patch clamp analysis. The present results thus suggest $\mathrm{Na}^{+}$influx through the NMDA channels is less sensitive than to a reduction of NR1 protein synthesis. This is very different to the issue of $\mathrm{Ca}^{2+}$ influx as excitotoxic cell death is reduced by both 5 and $20 \mu M$ of ANR1 (see below). This implies an application of low concentration of ANR1 may exert a lower degree of impairment as in the case of higher concentrations of ANR 1 in terms of NMDA receptor-mediated peak inward currents despite low and high concentrations are capable to reduce the gene expressions of NR1.

Different concentrations of ANR1 may affect the turnover of different pools of NR1 proteins that may in turn differentially affect the receptor physiology. Although this explanation remains hypothetical, previous studies $[45,46]$ have indicated that there are at least two degrading pools of NR 1 proteins, i.e. a fast and a slow degrading pool, found in cerebellar granule cells or in PC12 cells. A low concentration of ANR 1 is likely to be degraded quickly within the cytosol. In the case where higher concentrations of ANR1 are applied, a longer retention time of ANR1 within the neurons is expected. The fast degrading NR1 proteins demonstrated a half-life of $1.6 \mathrm{~h}$ and this pool of NR 1 proteins is most likely to be affected by both low and high concentrations of ANR1. Previous studies have demonstrated that intracerebral injections of antisense signals can be detected in the brain $16 \mathrm{~h}$ after the application [47, 48]. It is anticipated that the retention time of ANR1 inside neurons in culture may be even longer. The slow degrading pool of NR1 proteins were found to have a half-life of $16.1 \mathrm{~h}[45,46]$ and this pool of NR1 may be less likely to be affected by $5 \mu M$ of ANR 1 . The two pools of NR1 proteins are suggested to be composed of different splice variants, i.e. NR1-4a in fast degrading pool and NR1-2a in slow degrading pool, respectively [46]. There is no precise information about the functional roles of the two pools of NR1 proteins, e.g. their roles in $\mathrm{Na}^{+}$conductance in the NMDA receptor complex. It is also unknown whether the ANR1 has differential effects on the synthesis of the two splice variants of the NR1 protein. The present data thus suggest that at least there is such a possibility. The functional roles of different pools of NR1 proteins remain to be established. One useful tool in the future may be a splice variant specific ANR1.

In addition, the disparities between gene expressions and NMDA receptor physiology could be explained by the fact that RT-PCR, Western blotting and patch clamp analysis are different techniques with different detection sensitivities. A recent study shows that application of NR1 antisense oligos (a different sequence) to the rat spinal cord results in a $30 \%$ reduction of NR1 mRNA in the dorsal horn, whereas a 50\% reduction in NMDA receptor ligand binding is found [49]. These results are consistent with our present observation in striatal neurons and show that the effects of NR1 antisense can exert different degrees of impairment on NR1 gene expressions and on NMDA receptor functions. 


\section{Effects ANR1 on Phosphorylation of NR1 at Serine}

Residues

One straight observation of the present results demonstrates that ANR1 does not modulate the amount of phosphorylated NR1 proteins at two serine residues, ser896 and ser897. The present results, however, do not preclude the possibility that there is an increased level of phosphorylated NR1 proteins because there is an overall reduction of NR1 proteins after the antisense treatment. This increase in the phosphorylation level may be a mechanism that compensates the reduction of NR1 expression level. Despite the above uncertainty whether there is no change or an increase of total phosphorylated NR1 proteins, the present results are capable to demonstrate that the amounts of phosphorylated NR1 proteins are not reduced after antisense treatment.

Phosphorylation of the NR1 proteins is an important regulation of NMDA receptor functions [50, 51]. Phosphorylation of NR1 proteins affect the anchorage of the NMDA receptor to plasma membranes and the subcellular distribution of the receptor [52-54]. Interestingly, in parkinsonian animal models, conflicting results in terms of modulation of phosphorylated NR proteins have been described. Dunah et al. [55] have found a decrease of NR1 phosphorylation at ser890 and ser896 but no change in NR1 phosphorylation at ser897. However, subsequent study shows that a significant increases of phosphorylated NR1 proteins at ser897 has been found in the neostriatum of the rat model [56]. A recent report shows that ANR1 has been shown to ameliorate the parkinsonian motor symptoms in a rat parkinsonian model [28]. The present results directly demonstrate that ANR1 does not reduce the phosphorylation of NR1 proteins at these two serine residues. These results show that the beneficial effects of ANR1 in the parkinsonian rat model may not act upon the phosphorylation of NR1 protein. The precise roles of NR1 phosphorylation in the parkinsonian conditions remain to be established.

\section{ANRI Is an Effective Neuroprotective Agent}

Another novel finding of the present study is the neuroprotective effects of ANR1 on the striatal neurons against NMDA-induced excitotoxicity. Excitotoxic cell death is known to be mediated by influx of $\mathrm{Ca}^{2+}$ into neurons $[57,58]$. The present results indicate that the both 5 and $20 \mu M$ of ANR 1 are similar in terms of potency for neuroprotection. As discussed, both concentrations of ANR1 can reduce NR1 protein expression to a similar degree. This reduction in NR1 protein expression is presumed to reduce the number of $\mathrm{Ca}^{2+}$-permeable NMDA receptors in the neurons. Interestingly, the degree of neuroprotection against NMDA toxicity of ANR1 is similar to L-APV, a well-known competitive NMDA receptor antagonist that has neuroprotective potency [59]. These findings indicate that ANR1 may be developed in the future as a neuroprotective agent against excitotoxic cell death in motor disorders and other neurodegenerative diseases.

In summary, a single dose of ANR1 is effective in reduction of the gene expression of NR1 proteins in striatal neurons in culture. ANR1 is non-toxic and specific and this NR1-specific oligo directly modulates the NMDA channel activity and thus offers neuroprotection against NMDA-induced excitotoxicity in striatal neurons. Therefore, ANR1 may be a potential therapeutic agent in gene therapy and have implications in treatment of neurodegenerative diseases.

\section{Acknowledgements}

The present work was supported by Joint Research Scheme, National Natural Foundation of Science, China and Research Grants Council, Hong Kong, 30218002 and N_HKBU202/02, and Faculty Research Grants, FRG/00-01/II-51, FRG/01-02/I-18, Hong Kong Baptist University. P.W.L was supported by a postgraduate studentship, Hong Kong Baptist University. The authors would like to thank Miss L.Y. Man and Mr Kenny Ho for technical assistance. 


\section{References}

1 Mattson MP: Excitotoxic and excitoprotective mechanisms: abundant targets for the prevention and treatment of neurodegenerative disorders. Neuromolecular Med 2003;3:65-94.

2 Olney JW: Excitotoxicity, apoptosis and neuropsychiatric disorders. Curr Opin Pharmacol 2003;3:101-109.

-3 Blandini F, Porter RH, Greenamyre JT: Glutamate and Parkinson's disease. Mol Neurobiol 1996;12:73-94.

-4 Blandini F, Greenamyre JT, Nappi G: The role of glutamate in the pathophysiology of Parkinson's disease. Funct Neurol 1996;11:3-15.

5 Greenamyre JT: Glutamatergic influences on the basal ganglia. Clin Neuropharmacol 2001; 24:65-70.

-6 Li L, Fan M, Icton CD, Chen N, Leavitt BR, Hayden MR, Murphy TH, Raymond LA: Role of NR2B-type NMDA receptors in selective neurodegeneration in Huntington disease. Neurobiol Aging 2003;24:1113-1121.

7 Le DA, Lipton SA: Potential and current use of N-methyl- $D$-aspartate (NMDA) receptor antagonists in diseases of aging. Drugs Aging 2001;18:717-724.

8 Vanhoutte P, Bading H: Opposing roles of synaptic and extrasynaptic NMDA receptors in neuronal calcium signalling and BDNF gene regulation. Curr Opin Neurobiol 2003;13: 366-371.

-9 Hardingham GE, Bading H: The Yin and Yang of NMDA receptor signalling. Trends Neurosci 2003;26:81-89.

$\checkmark 10$ Buller AL, Larson HC, Schneider BE, Beaton JA, Morrisett RA, Monaghan DT: The molecular basis of NMDA receptor subtypes: native receptor diversity is predicted by subunit composition. J Neurosci 1994; 14:5471-5484.

11 Gasic GP, Hollmann M: Molecular neurobiology of glutamate receptors. Annu Rev Physiol 1992;54:507-536.

-12 Meguro H, Mori H, Araki K, Kushiya E, Kutsuwada T, Yamazaki M, Kumanishi T, Arakawa M, Sakimura K, Mishina M: Functional characterization of a heteromeric NMDA receptor channel expressed from cloned cDNAs. Nature 1992;357:70-74.

13 Monyer H, Sprengel R, Schoepfer R, Herb A, Higuchi M, Lomeli H, Burnashev N, Sakmann B, Seeburg PH: Heteromeric NMDA receptors: molecular and functional distinction of subtypes. Science 1992;256:1217-1221.

-14 Moriyoshi K, Masu M, Ishii T, Shigemoto R, 26 Mizuno N, Nakanishi S: Molecular cloning and characterization of the rat NMDA receptor. Nature 1991;354:31-37.

-15 Nakanishi S, Nakajima Y, Masu M, Ueda Y, Nakahara K, Watanabe D, Yamaguchi S, Kawabata S, Okada M: Glutamate receptors: brain function and signal transduction. Brain Res Brain Res Rev 1998;26:230-235.
16 Sun L, Margolis FL, Shipley MT, Lidow MS: Identification of a long variant of mRNA encoding the NR3 subunit of the NMDA receptor: its regional distribution and developmental expression in the rat brain. FEBS Lett 1998; 441:392-396.

17 Sun L, Shipley MT, Lidow MS: Expression of NR1, NR2A-D, and NR3 subunits of the NMDA receptor in the cerebral cortex and olfactory bulb of adult rat. Synapse 2000;35: 212-221.

18 Perez-Otano I, Schulteis CT, Contractor A, Lipton SA, Trimmer JS, Sucher NJ, Heinemann SF: Assembly with the NR1 subunit is required for surface expression of NR3A-containing NMDA receptors. J Neurosci 2001;21: 1228-1237.

19 Chatterton JE, Awobuluyi M, Premkumar LS, Takahashi H, Talantova M, Shin Y, Cui J, Tu S, Sevarino KA, Nakanishi N, Tong G, Lipton SA, Zhang D: Excitatory glycine receptors containing the NR3 family of NMDA receptor subunits. Nature 2002;415:793-798.

20 Wong HK, Liu XB, Matos MF, Chan SF, Perez-Otano I, Boysen M, Cui J, Nakanishi N, Trimmer JS, Jones EG, Lipton SA, Sucher NJ: Temporal and regional expression of NMDA receptor subunit NR3A in the mammalian brain. J Comp Neurol 2002;450:303-317.

21 Albin RL, Young AB, Penney JB: The functional anatomy of disorders of the basal ganglia. Trends Neurosci 1995;18:63-64.

-22 Li SH, Li XJ: Huntington-protein interactions and the pathogenesis of Huntington's disease. Trends Genet 2004;20:146-154.

23 Chen Q, Veenman CL, Reiner A: Cellular expression of ionotropic glutamate receptor subunits on specific striatal neuron types and its implication for striatal vulnerability in glutamate receptor-mediated excitotoxicity. Neuroscience 1996;73:715-731.

24 Gotz T, Kraushaar U, Geiger J, Lubke J, Berger T, Jonas P: Functional properties of AMPA and NMDA receptors expressed in identified types of basal ganglia neurons. J Neurosci 1997;17:204-215.

25 Thanos PK, Jhamandas K, Beninger RJ: Nmethyl- $D$-aspartate unilaterally injected into the dorsal striatum of rats produces contralateral circling: antagonism by 2-amino-7-phosphonoheptanoic acid and cis-flupenthixol. Brain Res 1992;589:55-61.

26 Lai SK, Wong CKC, Yang MS, Yung KKL: Changes in expression of N-methyl- $D$-aspartate receptor subunits in the rat neostriatum after a single dose of antisense oligonucleotide specific for $\mathrm{N}$-methyl- $D$-aspartate receptor one subunit. Neuroscience 2000;98:493-500.

27 Sze SCW, Wong CKC, Yung KKL: Modulation of the gene expression of N-methyl- $D$-aspartate receptor NR2B subunit in the rat neostriatum by a single dose of specific antisense oligodeoxynucleotide. Neurochem Int 2001; 39:319-327.
28 Lai SK, Ng TKY, Lau WK, Yang MS, Wong CKC, Chan YS, Yung KKL: Selective knockdown of gene expression of $\mathrm{N}$-methyl- $D$-aspartate receptor one ameliorates parkinsonian motor symptom in 6-hydroxydopamine-lesioned rats. Neurochem Int 2004;45:11-22.

29 Standaert DG, Testa CM, Rudolf GD, Hollingsworth ZR: Inhibition of N-methyl- $D$-aspartate glutamate receptor subunit expression by antisense oligonucleotides reveals their role in striatal motor regulation. J Pharmacol Exp Ther 1996;276:342-352.

30 Lui PW, Yung KKL: Antisense knockdown of gene expression of NMDA receptor subunits in striatal neurons in culture. Soc Neurosci Abstr 2001;27:296.1.

31 Lui PW, Yung WH, Yung KKL: Selective gene knockdown of NMDAR1 receptor affects NMDA channel activity. Soc Neurosci Abstr 2002;28:244.8.

- 32 Lui PW, Suen KC, Chan YS, Yung WH, Yung KKL: Striatal neurons but not nigral dopaminergic neurons in neonatal primary cell culture express endogenous functional N-methyl-Daspartate receptors. Brain Res Mol Brain Res 2003;120:9-21.

33 Lafon-Cazal M, Viennois G, Kuhn R, Malitschek B, Pin JP, Shigemoto R, Bockaert $\mathrm{J}$ : mGluR7-like receptor and GABA(B) receptor activation enhance neurotoxic effects of $\mathrm{N}$ methyl- $D$-aspartate in cultured mouse striatal GABAergic neurones. Neuropharmacology 1999;38:1631-1640.

-34 Lai SK, Tse YC, Yang MS, Wong CK, Chan YS, Yung KKL: Gene expression of glutamate receptors GluR1 and NR1 is differentially modulated in striatal neurons in rats after 6hydroxydopamine lesion. Neurochem Int 2003;43:639-653.

-35 Wong H, Anderson WD, Cheng T, Riabowol KT: Monitoring mRNA expression by polymerase chain reaction: the 'primer-dropping' method. Anal Biochem 1994;223:251-258.

36 Chan WS, Yeung CW, Chung EKY, Lau WK, Chan YS, Yung KKL: Differential expression of alpha-amino-3-hydroxy-5-methyl-4-isoxazole-propionate glutamate receptors in the rat striatum during postnatal development. Neurosignals 2003;12:302-309.

37 Lau WK, Lui PW, Wong CKC, Chan YS, Yung KKL: Differential expression of N-methyl-Daspartate receptor subunit messenger ribonucleic acids and immunoreactivity in the rat neostriatum during postnatal development. Neurochem Int 2003;43:47-65.

38 Yoshioka A, Ikegaki N, Williams M, Pleasure $\mathrm{D}$ : Expression of $\mathrm{N}$-methyl- $D$-aspartate (NMDA) and non-NMDA glutamate receptor genes in neuroblastoma, medulloblastoma, and other cells lines. J Neurosci Res 1996;46: 164-178. 
>39 Lau WK, Yeung CW, Lui PW, Cheung LH, Poon NT, Yung KKL: Different trends in modulation of NMDAR1 and NMDAR2B gene expression in cultured cortical and hippocampal neurons after lead exposure. Brain Res 2002;932:10-24.

-40 Dunah AW, Standaert DG: Dopamine D1 receptor-dependent trafficking of striatal NMDA glutamate receptors to the postsynaptic membrane. J Neurosci 2001;21:5546-5558.

-41 Hisatsune C, Umemori H, Inoue T, Michikawa T, Kohda K, Mikoshiba K, Yamamoto T: Phosphorylation-dependent regulation of $\mathrm{N}$ methyl- $D$-aspartate receptors by calmodulin. $\mathrm{J}$ Biol Chem 1997;272:20805-20810.

42 Tingley WG, Ehlers MD, Kameyama K, Doherty C, Ptak JB, Riley CT, Huganir RL: Characterization of protein kinase $\mathrm{A}$ and protein kinase $\mathrm{C}$ phosphorylation of the N-methyl$D$-aspartate receptor NR1 subunit using phosphorylation site-specific antibodies. J Biol Chem 1997;272:5157-5166.

43 Hollmann M, Heinemann S: Cloned glutamate receptors. Annu Rev Neurosci 1994;17:31108.

44 Nakanishi S: Molecular diversity of glutamate receptors and implications for brain function. Science 1992;258:597-603.

45 Huh KH, Wenthold RJ: Turnover analysis of glutamate receptors identifies a rapidly degraded pool of the N-methyl- $D$-aspartate receptor subunit, NR1, in cultured cerebellar granule cells. J Biol Chem 1999;274:151-157.
6 Vazhappilly R, Sucher NJ: Turnover analysis of N-methyl-D-aspartate receptor subunit NR1 protein in PC12 cells. Neurosci Lett 2002;318:153-157.

$\checkmark 47$ Ogawa S, Brown HE, Okano HJ, Pfaff DW: Cellular uptake of intracerebrally administered oligodeoxynucleotides in mouse brain. Regul Pept 1995;59:143-149.

48 Ogawa S, Pfaff DW: Application of antisense DNA method for the study of molecular bases of brain function and behavior. Behav Genet 1996;26:279-292.

49 Shimoyama N, Shimoyama M, Davis AM, Monaghan DT, Inturrisi CE: An antisense oligonucleotide to the $\mathrm{N}$-methyl- $D$-aspartate (NMDA) subunit NMDAR1 attenuates NMDA-induced nociception, hyperalgesia, and morphine tolerance. J Pharmacol Exp Ther 2005;312:834-840.

50 Gurd JW: Protein tyrosine phosphorylation: implications for synaptic function. Neurochem Int 1997;31:635-649.

51 Sigel E: Functional modulation of ligand-gated GABAA and NMDA receptor channels by phosphorylation. J Recept Signal Transduct Res 1995;15:325-332.

52 Dunah AW, Standaert DG: Dopamine D1 receptor-dependent trafficking of striatal NMDA glutamate receptors to the postsynaptic membrane. J Neurosci 2001;21:5546-5558.
53 Hisatsune C, Umemori $\mathrm{H}$, Inoue T, Michikawa T, Kohda K, Mikoshiba K, Yamamoto T: Phosphorylation-dependent regulation of $\mathrm{N}$ methyl- $D$-aspartate receptors by calmodulin. $\mathrm{J}$ Biol Chem 1997;272:20805-20810.

54 Tingley WG, Ehlers MD, Kameyama K, Doherty C, Ptak JB, Riley CT, Huganir RL: Characterization of protein kinase $\mathrm{A}$ and protein kinase C phosphorylation of the N-methyl$D$-aspartate receptor NR1 subunit using phosphorylation site-specific antibodies. J Biol Chem 1997;272:5157-5166.

5 Dunah AW, Wang Y, Yasuda RP, Kameyama K, Huganir RL, Wolfe BB, Standaert DG: Alterations in subunit expression, composition, and phosphorylation of striatal N-methyl- $D$ aspartate glutamate receptors in a rat 6-hydroxydopamine model of Parkinson's disease. Mol Pharmacol 2000;57:342-352.

56 Betarbet R, Poisik O, Sherer TB, Greenamyre JT: Differential expression and ser897 phosphorylation of striatal N-methyl- $D$-aspartate receptor subunit NR1 in animal models of Parkinson's disease. Exp Neurol 2004;187:7685 .

57 Choi DW: Excitotoxic cell death. J Neurobiol 1992;23:1261-1276.

58 Choi DW: Glutamate receptors and the induction of excitotoxic neuronal death. Prog Brain Res 1994;100:47-51.

59 Goldberg MP, Weiss JH, Pham PC, Choi DW: N-methyl- $D$-aspartate receptors mediate hypoxic neuronal injury in cortical culture. $\mathrm{J}$ Pharmacol Exp Ther 1987;243:784-791. 